\title{
Nondestructive and Rapid Estimation of Leaf Chlorophyll Content of Sugarcane using a SPAD Meter
}

\author{
Radhamani, R. ${ }^{1}$, R. Kannan ${ }^{2}$ \\ ${ }^{1}$ Assistant Professor, Department of Chemistry, College of Science, P. O. Box: 12676, Eritrea Institute of Technology, Mai Nafhi, Asmara, \\ Eritrea, N. E. Africa
}

${ }^{2}$ Lecturer, Department of Physics, Eritrea Institute of Technology, Mai Nafhi, Asmara, Eritrea, N. E. Africa

\begin{abstract}
This study evaluated the feasibility of using a SPAD-502 (Minolta, Japan) chlorophyll meter for estimating leaf chlorophyll and active iron content of sugarcane with respect to combined application of amendments. The SPAD chlorophyll meter readings were used to measure the leaf greenness. Leaf chlorophyll contents were also determined using the acetone extraction method. The metabolically active iron content of leaf was analysed by 1,10-orthophenanthroline extract. SPAD readings were significantly correlated with leaf chlorophyll content, cane yield, sugar yield and active iron contents were $0.900,0.723,0.711$ and 0.860 respectively. These results suggest that the readings from a SPAD meter can be used for rapidly and nondestructively estimating leaf chlorophyll and it could facilitate in-situ decision making for application of amendments to iron deficiency for the perfection of sugarcane yield.
\end{abstract}

Keywords: Sugarcane, SPAD meter, chlorophyll content, chlorosis, active iron.

\section{Introduction}

Sugarcane (Saccharum officinarum) is one of the most important commercial crops in India and plays a key role in the Indian economy. It is grown in an area of 4.83 million hectares during 2006-07 with a production of 345 million tonnes of cane. Sugar industry is the second largest agrobased industry and there are 501 sugar mills in the country producing 28.33 million tonnes of white sugar. In India, the deficiencies of some micronutrients in sugarcane have been observed in light textured soils, calcareous soils and highly alkaline or acid leached soils. Serious deficiency of micronutrients, particularly, iron and zinc have sharply focused the attention of soil scientists in recent years. Iron, an important micronutrient is present in abundant quantity in soils; but its availability to crops and its utilization are limited by several factors. Iron is essential for chlorophyll synthesis, protein formation, photosynthesis, electron transfer, oxidation and reduction of nitrates and sulphates and enzymatic activities. Iron exists in soil as oxides, carbonates, hydroxides and organic compounds. Among the various forms, ferrous iron (reduced form) is available to crops whereas ferric (oxidized) form is not available. Presence of adequate amount of biologically active iron $\left(\mathrm{Fe}^{2+}\right)$ is very important for optimum photosynthesis. Iron deficiency causes interveinal chlorosis in newly emerged leaves due to reduced chlorophyll synthesis resulting in reduced photosynthesis, poor growth, yield and quality. Iron chlorosis is more frequently noticed in sugarcane crop than in others due to higher removal of iron. Singh (1972) observed cane yield loss as high as $74 \%$ and reduction in sucrose content to the tune of $42 \%$ due to iron deficiency. Hence this study was taken up to alleviate iron deficiency and to identify tolerant varieties to this malady using SPAD meter reading as an indicator for chlorophyll content and active iron content of foliage and sugarcane yield.

\section{Materials and Methods}

An investigation was carried out at Research Farm of Sugarcane Breeding Institute, Coimbatore to study the effect of amelioration for iron deficiency and the response of sugarcane varieties to iron nutrition in a sandy loam iron deficient soil (Typic Haplustert) by planting 24 sugarcane clones/varieties with two treatments viz., control and combined application of amendments (organic manure -10 $\mathrm{t} / \mathrm{ha}+$ iron fortified organic manure $-2.5 \mathrm{t} / \mathrm{ha}+$ gypsum $7.5 \mathrm{t} / \mathrm{ha}+$ sulphur $-0.5 \mathrm{t} / \mathrm{ha})$. Initial soil sample was collected and analysed for various physico-chemical properties using standard procedures (Table 1). The soil of the experimental field was alkaline in reaction $(\mathrm{pH} 8.51)$ with the EC of $0.26 \mathrm{dS} \mathrm{m}^{-1}$. The soil was low in available nitrogen $\left(264 \mathrm{~kg} \mathrm{ha}^{-1}\right)$ with high available phosphorus $(40 \mathrm{~kg}$ $\left.\mathrm{ha}^{-1}\right)$ and potassium $\left(816 \mathrm{~kg} \mathrm{ha}^{-1}\right)$. The soil had organic carbon content of 0.59 per cent and the soil was deficient in available iron $(3.20 \mathrm{ppm})$ while available zinc $(2.10 \mathrm{ppm})$ was above critical level.

Table 1: Basic properties and nutrient status of the experimental field

\begin{tabular}{|c|c|c|}
\hline S. No. & \multicolumn{2}{|c|}{ Soil Character } \\
\hline 1 & Textural class & Sandy clay loam \\
\hline 2 & $\mathrm{pH}$ & 8.51 \\
\hline 3 & EC $\left(\mathrm{dS} \mathrm{m}{ }^{-1}\right)$ & 0.26 \\
\hline 4 & Organic carbon $(\%)$ & 0.59 \\
\hline 5 & Available N $\left(\mathrm{kg} \mathrm{ha}^{-1}\right)$ & 264 \\
\hline 6 & Available P $\left(\mathrm{kg} \mathrm{hsa}^{-1}\right)$ & 40 \\
\hline 7 & Available K $\left(\mathrm{kg} \mathrm{ha}^{-1}\right)$ & 816 \\
\hline 8 & Available Fe $(\mathrm{ppm})$ & 3.20 \\
\hline 9 & Available $\mathrm{Zn}(\mathrm{ppm})$ & 2.10 \\
\hline
\end{tabular}

The chlorophyll meter reading was taken in the first fully expanded leaf from the top at $120^{\text {th }}$ day after planting by using Minalto SPAD 502 chlorophyll meter. Ten SPAD readings were taken around the midpoint of each leaf and 


\section{International Journal of Science and Research (IJSR) \\ ISSN (Online): 2319-7064 \\ Index Copernicus Value (2013): 6.14 | Impact Factor (2015): 6.391}

averaged its values. The same randomly selected leaves were collected from individual plots and the midribs were removed. The mid portions were cut into small pieces with stainless steel scissors and the leaf samples were taken for chlorophyll analysis (Arnon, 1949) and active iron (Katyal and Sharma, 1980). The soil samples were collected at tillering stage $\left(120^{\text {th }}\right.$ day), and anlaysed $\mathrm{pH}, \mathrm{EC}, \mathrm{OC}$ and for available nutrients $(\mathrm{N}, \mathrm{P}, \mathrm{K}, \mathrm{Fe}$ and $\mathrm{Zn})$. The crop was harvested at maturity ( $12^{\text {th }}$ month) and cane yield was recorded for each plot and sugar yield was computed using commercial cane sugar percent and cane yield.

\section{Results and Discussion}

The chlorophyll meter reading, chlorophyll content, metabolically active iron content, cane yield and sugar yield was improved due to ameliorative treatment for iron deficiency regardless of varieties (Table 2). Among the twenty four sugarcane clones/varieties investigated, five varieties namely, Co 8021, Co 86032, Co 88025, Co 88028 and Co 94005 did not produce chlorosis and the varieties Co 419, Co 7219, Co 85019, Co 86010, Co 87025 and Co 94003 showed severe chlorosis. Remaining varieties showed moderate effect in control plot. While in ameliorative plot none of varieties showed chlorosis (Plate 1).

\section{SPAD meter reading}

About hundred per cent increase of SPAD reading was noticed due to ameliorative treatment (32.5) over control (15.9). Varieties, Co 8021, Co 86032, Co 88025, Co 88028 and Co 92020 recorded higher chlorophyll meter reading ( $>$ 18.4 in control and $>34.0$ in ameliorated plot) and Co 740, Co 7219, Co 86010, Co 87025, Co 94003 and 971862 registered lower chlorophyll meter reading $(<13.6$ in control and $>31.0$ in ameliorated plot) in both control and ameliorative treatment. In ameliorative plot, the chlorophyll meter reading varied from 25.4 to 39.3 with the mean of 32.5 (plate. 1a) and in control plot, it varied from 6.2 to 28.6 with the mean of 15.9 (plate. 1b).

Chlorophyll meter reading is an indirect measure of chlorophyll content in leaf blade. Since the chlorosis is mainly due to iron deficiency, the chlorophyll meter reading reflects the effect of amendments on iron availability and concentration of active iron in leaf blade as well as chlorophyll content. Different plant characteristics were used to assess the plant iron nutritional status to observe the effectiveness of the ameliorants. The plant characteristics most affected by iron chlorosis and the leaf SPAD index that markedly increased in ameliorated plot over control. Significant correlations were found between SPAD reading and chlorophyll content $\left(\mathrm{r}=0.900^{* *}\right)$, active iron content of leaf index $\left(\mathrm{r}=0.860^{* *}\right)$. The use of SPAD with other few plants has been tried by Westerveld et al., 2004 and Yan-Ju Liu et a1., 2006 and results showed that using SPAD to monitor tissue nutrient is easy and cost advantageous. However, in general, the use of SPAD with other crops has rarely been reported.

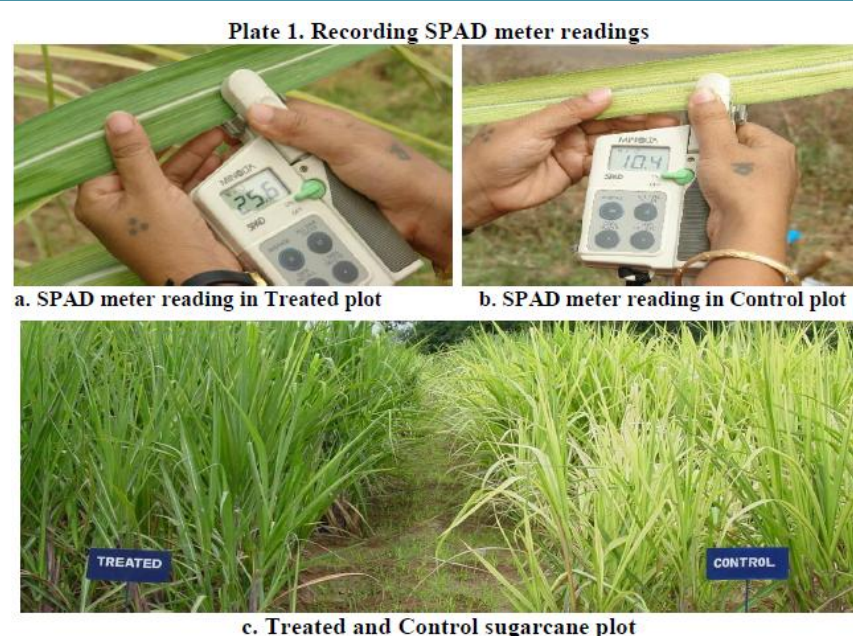

Plate 1: Recording SPAD meter readings

\section{Total chlorophyll content}

Total chlorophyll content of leaves followed the same trend as that of SPAD readings. In the control plot, $70 \%$ of the varieties showed varying degree of chlorosis indicating differential varietal response to iron deficiency except Co 8021, Co 86032, Co 88025, Co 92020 and Co 94005. None of the varieties expressed chlorosis in the ameliorated plot (Plate 1c). About three-fold increase in mean chlorophyll content $\left(0.376\right.$ to $\left.1.206 \mathrm{mg} \mathrm{g}^{-1}\right)$ was observed due to amelioration treatment over control. In the control plot, it varied from 0.139 to $0.993 \mathrm{mg} \mathrm{g}^{-1}$ with the mean of 0.376 $\mathrm{mg} \mathrm{g}^{-1}$ while in ameliorative plot it ranged from 0.818 to $2.305 \mathrm{mg} \mathrm{g}^{-1}$ with the grand mean of $1.206 \mathrm{mg} \mathrm{g}^{-1}$ of fresh weight. With respect to varieties, Co 8021, Co 86032 and Co 92020 recorded higher chlorophyll content $\left(>0.467 \mathrm{mg} \mathrm{g}^{-1}\right.$ in control and $>1.331 \mathrm{mg} / \mathrm{g}$ in ameliorated plot) while lower content was registered in Co 419, Co 740, Co 87025, Co 91010 and Co $93009\left(<0.285 \mathrm{mg} \mathrm{g}^{-1}\right.$ in control and $<1.080$ $\mathrm{mg}^{-1}$ in ameliorated plot). A phenomenal increase in chlorophyll content was observed in these clones. This clearly indicates that Co 419, Co 740, Co 87025, Co 91010 and Co 93009 are more susceptible to iron deficiency and inefficient utilizer of iron. The varieties Co 8021, Co 86032 and Co 92020 recorded higher chlorophyll content in both control and ameliorated plot revealed that resistance to iron deficiency being an efficient utilizer of soil iron.

The results of the study revealed an increase in the total chlorophyll content as a result of combined application of amendments. Iron is essential for the synthesis of chlorophyll. When iron becomes limiting, the chlorophyll synthesis slows down and the chlorophyll gets diluted due to continuous leaf expansion (Miller et al., 1982). Hence increased availability of Fe with the application of various amendments improved the chlorophyll content of leaves. The positive correlation was observed between active iron and total chlorophyll content of leaves $\left(\mathrm{r}=0.933^{* *}\right)$. Marsh et al. (1963) and Terry and Low (1982) also reported close correlation between chlorophyll content of leaves and iron content. The soil of the experimental field was deficient in iron with substantial amount of $\mathrm{CaCO}_{3}$. This could have interfered with iron nutrition and hence combined application showed better response. Marsh et al., (1963) pointed out the importance of iron in the formation of 


\section{International Journal of Science and Research (IJSR) \\ ISSN (Online): 2319-7064 \\ Index Copernicus Value (2013): 6.14 | Impact Factor (2015): 6.391}

chlorophyll due to its role in the formation of $\alpha-$ aminoleveulinic acid. Deficiency of iron may therefore restrict chlorophyll synthesis and consequently lead to chlorosis. This explanation holds true for the increased chlorophyll content observed in the leaf tissues of clones grown in iron deficient condition under combined application treatment and was chlorotic in the control treatment. The variability in the chlorophyll content among varieties was also seen. It might be due to genetic variability on impairing iron availability to the crop.

\section{Metabolically active iron content}

The importance of $\mathrm{Fe}^{2+}$ content of leaves in imparting chlorotic symptoms was well evidenced by the low $\mathrm{Fe}^{2+}$ content in susceptible varieties under iron deficient conditions while in the tolerant varieties high active iron content and the plants were free from chlorosis. The metabolically active iron content between the treatments, the control recorded lower active iron content of $209 \mathrm{ppm}$ than the ameliorative treatment (385 ppm). The improvement due to ameliorative treatment was about $84 \%$. Among the varieties, Co 8021, Co 86032 and Co 88028 recorded higher active iron content in both control and ameliorative treatment $(>231 \mathrm{ppm}$ in control and $>412 \mathrm{ppm}$ in ameliorated plot). The lower active iron content was noticed in Co 740, Co 86027, Co 87025, Co 91010, Co 93009, Co 94008, Co 97001 and Co 97008 (<188 ppm) in the control plot while in ameliorative plot Co 7219, Co 87025, Co 88025, Co 89010, Co 91010, Co 93009 and Co 97001 recorded lower active iron content of $<359 \mathrm{ppm}$.

Chlorotic plants should be evaluated by the quantification of active iron (Katyal and Sharma, 1980 and Zohlen, 2000). Active iron $\left(\mathrm{Fe}^{2+}\right)$ is fundamental in the synthesis of protoporphirine IX, the precursor of chlorophylls, the close relationship of $\mathrm{Fe}^{2+}$ to chlorophylls and chlorosis makes the determination of $\mathrm{Fe}^{2+}$ a good indicator of the nutrient status of crops. Orthophenanthroline extractable iron which is the physiologically active fraction of iron correctly reflects the iron status of the plant. It is worth to mention here that the susceptible varieties exhibited well defined iron deficiency symptoms in iron deficient conditions. However, the tolerant varieties the symptom was absent. The metabolically active iron $\left(\mathrm{Fe}^{2+}\right)$ decreased with the increasing intensity of iron chlorosis (Gupta et al., 2004). In the present study the active iron increased with increasing chlorophyll and SPAD readings as evidenced from the positive association of active iron with chlorophyll content $\left(\mathrm{r}=0.933^{* *}\right)$ and SPAD reading $\left(\mathrm{r}=0.860^{* *}\right)$. This is in accordance with the suggestions of Oserkowsky (1933) that significant variation occurred between active Fe content and chlorophyll content.

\section{Cane yield}

Iron chlorosis can limit crop yield, especially on calcareous soil. Typical management for iron chlorosis includes the use of iron fertilizers, various amendments or chlorosis tolerant cultivars. Yield improvement was observed in all the varieties in varying levels due to ameliorative treatment over control. The ameliorative treatment recorded higher cane yield of $84.5 \mathrm{t} \mathrm{ha}^{-1}$ than the control $\left(56.2 \mathrm{t} \mathrm{ha}^{-1}\right)$. In the control plot the cane yield ranged from 15 to $99 \mathrm{t} \mathrm{ha}^{-1}$ with the mean of $56.2 \mathrm{t} \mathrm{ha}^{-1}$, while in the ameliorated plot it varied from 55 to $126 \mathrm{t} \mathrm{ha}^{-1}$ with the mean of $84.5 \mathrm{t} \mathrm{ha}^{-1}$. The improvement due to ameliorative treatment was $52 \%$ over control in cane yield.

Varieties/clones Co 8021, Co 85019, Co 86032, Co 86249, Co 88028 , Co 94005 and Co 94012 were found relatively tolerant to iron deficiency and recorded fairly good yield in control also ( $>68 \mathrm{t} \mathrm{ha}^{-1}$ in control and $>94 \mathrm{t} \mathrm{ha}^{-1}$ in ameliorated plot). These varieties could be recommended for cultivation in iron deficient soils. While Co 419, Co 740, Co 7219, Co 86010, Co 86027, Co 87025, Co 91010, Co 93009 and Co 94003 were highly susceptible to this malady and recorded less than $44 \mathrm{t} \mathrm{ha}^{-1}$ in control and in ameliorated plot also these varieties recorded low yield $\left(<75 \mathrm{t} \mathrm{ha}^{-1}\right)$. These varieties could be used as an indicator variety to detect iron deficiency in soil (Rakkiyappan et al., 2002), which exhibited higher intensity of chlorosis as revealed by chlorophyll content and SPAD meter reading, yielded much lower than others, indicating thereby, an adverse effect of chlorosis on crop yield.

The cane yield seemed to be associated with the active $\mathrm{Fe}$ content of the plants as supported by a significant correlation $\left(\mathrm{r}=0.718^{* *}\right)$. The SPAD reading and chlorophyll content also showed significant relationship $\left(\mathrm{r}=0.723^{* *}\right.$ and $\mathrm{r}=$ $\left.0.753^{* *}\right)$ with the cane yield. Varietal differences were noticed markedly in respect of their yield, occurrence of chlorosis, leaf active iron and chlorophyll content (Chhibba et al., 2004 and Radhamani et al., 2015). Lingenfelser et al. (2005) proved that using resistant genotypes to be the most effective treatment in reducing chlorosis scores and yield loss. This agrees with the results of Naeve and Rehm (2006). Cane yield was improved due to application of ferrous sulphate, sulphur and zinc sulphate (Tomer and Malik, 2004). Sharma et al. (2006) reported that application of gypsum gave maximum cane yield with the proper tune of quality. It is due to improved soil condition which may result into optimum uptake of plant nutrients from the soil and thereby ultimately resulted into per hectare higher cane yield. Varietal difference in cane yield was reported by Osman et al. (2006) and Radhamani et al. (2015). The cane yield of sugarcane varieties Co 86249 and CoC 99061 were significantly higher due to application of sulphur (Saravanan et al., 2006). Singh et al. (2002) reported that application of amendments viz., gypsum, pyrites and FYM singly and in combinations to sodic soils reduced the $\mathrm{pH}$ of soils and increased the yield.

\section{Sugar yield}

The ameliorative treatment recorded higher sugar yield of $11.45 \mathrm{t} \mathrm{ha}^{-1}$ than the control $\left(7.16 \mathrm{t} \mathrm{ha}^{-1}\right)$ with $60 \%$ improvement. The varieties Co 8021, Co 85019, Co 86032, Co 86249, Co 88028, Co 94005 and Co 94012 recorded relatively higher sugar yield in ameliorated plot as well as in the control plot. The lowest sugar yield was 


\section{International Journal of Science and Research (IJSR) \\ ISSN (Online): 2319-7064}

Index Copernicus Value (2013): 6.14 | Impact Factor (2015): 6.391

Table 2: Effect of ameliorative treatment on SPAD reading, chlorophyll content, active Fe, cane yield and sugar yield of 24 sugarcane varieties

\begin{tabular}{|c|c|c|c|c|c|c|c|c|c|c|c|}
\hline \multirow[t]{2}{*}{ S. No. } & \multirow{2}{*}{ Clones / Varieties } & \multicolumn{2}{|c|}{ SPAD reading } & \multicolumn{2}{|c|}{$\begin{array}{c}\text { Chlorophyll } \\
\text { Content }\left(\mathrm{mg} \mathrm{g}^{-1}\right)\end{array}$} & \multicolumn{2}{|c|}{$\begin{array}{c}\text { Active Fe } \\
\text { (ppm) }\end{array}$} & \multicolumn{2}{|c|}{$\begin{array}{c}\text { Cane yield } \\
\left(\mathrm{t} \mathrm{ha}^{-1}\right)\end{array}$} & \multicolumn{2}{|c|}{$\begin{array}{c}\text { Sugar yield } \\
\left(\mathrm{tha}^{-1}\right)\end{array}$} \\
\hline & & $\mathrm{C}$ & $\mathrm{T}$ & $\mathrm{C}$ & $\mathrm{T}$ & $\mathrm{C}$ & $\mathrm{T}$ & $\mathrm{C}$ & $\mathrm{T}$ & $\mathrm{C}$ & $\mathrm{T}$ \\
\hline 1 & Co 419 & 9.1 & 33.2 & 0.146 & 0.947 & 188 & 363 & 42 & 61 & 5.08 & 7.84 \\
\hline 2 & Co 740 & 11.4 & 30.9 & 0.224 & 0.925 & 169 & 363 & 42 & 67 & 4.64 & 7.49 \\
\hline 3 & Co 7219 & 13.2 & 28.4 & 0.414 & 1.118 & 206 & 356 & 19 & 69 & 1.98 & 8.11 \\
\hline 4 & Co 8021 & 26.0 & 39.3 & 0.859 & 2.305 & 306 & 506 & 97 & 125 & 13.84 & 18.60 \\
\hline 5 & Co 85019 & 10.7 & 34.9 & 0.312 & 1.111 & 256 & 375 & 81 & 123 & 10.06 & 16.19 \\
\hline 6 & Co 86010 & 9.5 & 29.4 & 0.182 & 1.152 & 188 & 431 & 42 & 64 & 4.83 & 8.42 \\
\hline 7 & Co 86027 & 15.9 & 38.4 & 0.282 & 1.153 & 181 & 400 & 26 & 56 & 2.13 & 7.77 \\
\hline 8 & Co 86032 & 28.4 & 36.6 & 0.758 & 1.652 & 281 & 500 & 99 & 126 & 13.53 & 15.42 \\
\hline 9 & Co 86249 & 14.6 & 31.4 & 0.276 & 1.245 & 189 & 363 & 96 & 101 & 13.83 & 19.06 \\
\hline 10 & Co 87025 & 10.7 & 25.4 & 0.220 & 1.008 & 143 & 308 & 15 & 55 & 1.55 & 6.46 \\
\hline 11 & Co 88025 & 22.6 & 36.1 & 0.637 & 1.209 & 244 & 340 & 67 & 91 & 8.28 & 12.17 \\
\hline 12 & Co 88028 & 22.7 & 36.5 & 0.374 & 1.633 & 269 & 494 & 82 & 104 & 11.03 & 14.36 \\
\hline 13 & Co 89010 & 15.8 & 30.4 & 0.304 & 1.048 & 188 & 350 & 64 & 78 & 8.57 & 11.08 \\
\hline 14 & Co 91010 & 16.1 & 31.7 & 0.248 & 0.838 & 150 & 300 & 20 & 64 & 2.51 & 8.65 \\
\hline 15 & Co 92020 & 18.8 & 25.7 & 0.620 & 1.355 & 313 & 406 & 22 & 89 & 2.53 & 11.51 \\
\hline 16 & Co 93009 & 15.6 & 34.0 & 0.279 & 0.818 & 181 & 319 & 40 & 62 & 5.89 & 7.86 \\
\hline 17 & Co 94003 & 6.2 & 29.6 & 0.139 & 1.089 & 188 & 406 & 34 & 62 & 4.20 & 8.85 \\
\hline 18 & Co 94005 & 28.6 & 31.8 & 0.993 & 1.223 & 313 & 366 & 97 & 105 & 12.25 & 14.68 \\
\hline 19 & Co 94008 & 13.7 & 33.4 & 0.207 & 1.167 & 170 & 469 & 81 & 92 & 9.19 & 11.90 \\
\hline 20 & Co 94012 & 13.6 & 31.3 & 0.325 & 0.927 & 193 & 360 & 98 & 114 & 13.75 & 17.86 \\
\hline 21 & Co 97001 & 13.7 & 32.6 & 0.291 & 1.125 & 175 & 201 & 21 & 82 & 2.34 & 9.73 \\
\hline 22 & Co 97008 & 18.4 & 37.4 & 0.333 & 1.330 & 131 & 438 & 48 & 79 & 5.51 & 9.65 \\
\hline 23 & Co 97009 & 16.3 & 32.6 & 0.305 & 1.229 & 219 & 413 & 54 & 72 & 6.45 & 9.30 \\
\hline 24 & 971862 & 11.3 & 29.0 & 0.303 & 1.336 & 188 & 425 & 61 & 88 & 7.88 & 11.77 \\
\hline & Mean & 15.9 & 32.5 & 0.376 & 1.206 & 209 & 385 & 56.2 & 84.5 & 7.16 & 11.45 \\
\hline & SD & 5.99 & 3.70 & 0.23 & 0.314 & 53 & 65 & 30 & 23 & 4.22 & 3.81 \\
\hline & CI & 2.40 & 1.48 & 0.090 & 0.126 & 21 & 26 & 12 & 9 & 1.69 & 1.52 \\
\hline & UCI & 18.4 & 34.0 & 0.467 & 1.331 & 231 & 412 & 68 & 94 & 8.85 & 12.97 \\
\hline & LCI & 13.6 & 31.0 & 0.285 & 1.080 & 188 & 359 & 44 & 75 & 5.47 & 9.92 \\
\hline
\end{tabular}

C - Control, T - Treated, SD - Standard Deviation, CI - Confidence Interval,

UCI - Upper Confidence Interval, LCI - Lower Confidence Interval.

recorded in the varieties Co 419, Co 740, Co 7219, Co 86010, Co 86027, Co 87025, Co 91010, Co 92020 and Co 94003 even in ameliorated plot. In control plot, the sugar yield ranged from 1.55 (Co 87025) to $13.84 \mathrm{t} \mathrm{ha}^{-1}$ (Co 8021) with the mean of $7.16 \mathrm{t} \mathrm{ha}^{-1}$ while in ameliorated plot 6.46 (Co 87025) to $19.06 \mathrm{t} \mathrm{ha}^{-1}$ (Co 86249) with the mean of $11.45 \mathrm{t} \mathrm{ha}^{-1}$. Kannapan (2006) reported that application of sulphur, gypsum and ammonium phosphate sulphate was essential for getting the maximum sugar yield. The varieties recorded higher cane yield also gave higher sugar yield as could be seen from the positive association $\left(\mathrm{r}=0.971^{* *}\right)$ between cane yield and sugar yield. There was also a significant correlation between SPAD meter reading and sugar yield $\left(\mathrm{r}=0.711^{* *}\right)$.

Significant increase in sugar and cane yield due to sulphur, gypsum application was observed (Jamal et al., 2003; Shukla and Menhilal, 2002). Treatments containing Fe were generally effective in increasing the chlorophyll concentration of iron deficient sugarcane leaves. The combined application of amendments was the more effective for ameliorating the iron deficiency of sugarcane.

\section{The effect of ameliorative treatment on soil characters}

Iron chlorosis is a widely occurring nutritional malady of sugarcane, especially in calcareous soils. Iron is essential for processes such as photosynthesis, respiration, nitrogen fixation and for DNA, chlorophyll and hormone synthesis. Although iron is one of the micronutrients, its chemistry is so influenced by various factors that even when high amount of total iron is present in the soil, visible symptoms of iron deficiency are observed. The ameliorative treatment showed significant effect on plant characteristics as well as yielded superior over control due to improved soil properties (Table $3)$.

\section{Correlation between SPAD reading and other parameters}

SPAD readings were significantly correlated with total chlorophyll content, metabolically active iron content, cane yield and sugar yield of sugarcane (Table 4). This result suggests that the portable chlorophyll meter may be suitable to use for the estimation of leaf chlorophyll content and active iron content of sugarcane plants. 


\section{International Journal of Science and Research (IJSR) \\ ISSN (Online): 2319-7064}

Index Copernicus Value (2013): 6.14 | Impact Factor (2015): 6.391

Table 3: Effect of ameliorative treatment on soil characters at tillering stage

\begin{tabular}{|c|c|c|c|}
\hline S. No. & Soil character & Control & Treated \\
\hline 1 & $\mathrm{pH}$ & 8.36 & 7.24 \\
\hline 2 & $\mathrm{EC}\left(\mathrm{dS} \mathrm{m}{ }^{-1}\right)$ & 0.60 & 0.79 \\
\hline 3 & Organic carbon $(\%)$ & 0.59 & 0.72 \\
\hline 4 & Available N $\left(\mathrm{kg} \mathrm{h}^{-1}\right)$ & 272 & 286 \\
\hline 5 & Available $\mathrm{P}\left(\mathrm{kg} \mathrm{hsa}^{-1}\right)$ & 57 & 69 \\
\hline 6 & Available K $\left(\mathrm{kg} \mathrm{h}^{-1}\right)$ & 910 & 986 \\
\hline 7 & Available Fe $(\mathrm{ppm})$ & 3.46 & 4.51 \\
\hline 8 & Available $\mathrm{Zn}(\mathrm{ppm})$ & 3.65 & 4.50 \\
\hline
\end{tabular}

Table 4: Interrelationship (r) among SPAD reading and other parameters as influenced by ameliorative treatment on twenty four sugarcane varieties

\begin{tabular}{|c|c|c|c|c|c|}
\hline & SPAD & $\begin{array}{c}\text { Total } \\
\text { chlorophyll }\end{array}$ & $\begin{array}{c}\text { Active } \\
\text { Iron }\end{array}$ & $\begin{array}{c}\text { Cane } \\
\text { yield }\end{array}$ & $\begin{array}{c}\text { Sugar } \\
\text { Yield }\end{array}$ \\
\hline SPAD & 1 & $0.900^{* *}$ & $0.860^{* *}$ & $0.723^{* *}$ & $0.711^{* *}$ \\
\hline Total chlorophyll & & 1 & $0.933^{* *}$ & $0.753^{* *}$ & $0.747^{* *}$ \\
\hline Active Iron & & & 1 & $0.718^{* *}$ & $0.674^{* *}$ \\
\hline Cane yield & & & & 1 & $0.971^{* *}$ \\
\hline Sugar Yield & & & & & 1 \\
\hline
\end{tabular}

** - significant at $1 \%$ level

\section{Conclusion}

The present work demonstrated that foliar chlorophyll and metabolically active iron content could be reliably estimated using the SPAD-502 meter. This method is simple, nondestructive and quickly reports a large number of readings. The portable chlorophyll meter readings (SPAD readings) may provide an efficient means by which to monitor the Fe deficiency of sugarcane and to ameliorate the iron chlorosis. From the present work, it can also be concluded that the combined application of amendments for iron deficiency may be a good way to increase the yield of sugarcane under iron deficient condition. Based on the comparison among plant and yield parameters, the varieties Co 8021, Co 86032, Co 86249, Co 88028, Co 94005 and Co 94012 were recommended for cultivation under iron deficient condition, varieties Co 7219, Co 86010, Co 87025 and Co 91010 could serve as indicator varieties to detect iron deficiency in soils.

\section{Acknowledgement}

Authors are grateful to Director, Sugarcane Breeding Institute (ICAR), Coimbatore for providing permission and facilities for taking up this study.

\section{References}

[1] Arnon, D.I. 1949. Copper enzymes in isolated chloroplasts. Polyphenoxidase in Beta vulgaris. Pl. Physiol., 24: 1-5.

[2] Chhibba, I.M., V.K. Nayyar, M.L. Kapur and J. Singh. 2004. Varietal differences in chlorosis, yield and nutrient composition in sugarcane grown on a typic Ustochrept. Indian J. Sug. Cane Technol., 19(1\&2): 7882.

[3] Gupta, V.K., A.K. Singh and R.C. Pant. 2004. The effect of iron deficiency on root morphology, ethylene content and uptake of other micronutrients in vitro grown cultivars of sugarcane. Indian J. Pl. Physiol. 9(2): 124-131.

[4] Jamal, A., S. Ahmad, S. Kumari, I.S. Fazli, R.U. Rahman and M.Z. Adiu. 2003. Nitrogen and sulphur nutrition enhances seed and oil yield of groundnut (Arachis hypogaea) Intl. Cong. Pl. Physiol., Jan 8-12, New Delhi, India, p 395.

[5] Kannapan, K. 2006. Effect of levels and different sources and quantity of sulphur application on sugarcane yield and quality. Indian Sug., 56(1): 25-28.

[6] Katyal, J.C. and B.D. Sharma. 1980. A new technique of plant analysis to resolve iron chlorosis. $\mathrm{Pl}$. Soil, 55: 105-119.

[7] Lingenfelser, J.E., W.T. Jr., Schapaugh, J.P. Schmidt and J.J. Higgins. 2005. Comparison of genotype and cultural practices to control iron deficiency chlorosis in soybean. Commun. Soil Sci. Pl. Anal., 36: 1047-1062.

[8] Marsh, H.V., H.J. Evans and G. Matrone. 1963. Investigations of the role of iron in chlorophyll metabolism. II. Effect of iron deficiency on chlorophyll synthesis. Pl. Physiol., 38: 638-642.

[9] Miller, G.W., A. Denny, J. Pushnik and M.H. Yu. 1982. The formulation of delta aminolevulinate: A precursor of chlorophyll in barley and the role of iron. $J$. Pl. Nutri., 5: 289-300.

[10] Naeve, S.L. and G.W. Rehm. 2006. Genotype x environment interactions within iron deficiency chlorosis tolerant soybean genotypes. Agron. J., 98: 808-814.

[11] Oserkowsky, J. 1933. Quantitative relation between chlorophyll and iron in green plants and chlorotic pear leaves. Pl. Physiol., 8: 449.

[12] Osman, A.M., G. Vijaya Kumar, U.S. Natarajan and C. Babu. 2006. Investigations on sugar cane families for ratooning ability and iron chlorosis tolerance under field conditions. Indian Sug., 56(8): 25.

[13]Radhamani, R, R. Kannan and P. Rakkiyappan. 2015. Leaf chlorophyll meter readings as an indicator for sugarcane yield under iron deficient Typic Haplustert. Sugar Tech. DOI 10.1007/s12355-014-0363-9.

[14] Rakkiyappan, P., S. Thangavelu and R. Radhamani. 2002. Effect of ferrous sulphate on sugarcane varieties grown in iron deficient soil. Sugar Tech., 4(1-2): 33-37.

[15] Saravanan, S., S. Subramanian, M. Soundarajan and B. Rajendran. 2006. Effect of sources and levels of sulphur on yield and quality of sugarcane. Indian Sug., $\mathbf{5 6}(\mathbf{8})$ : $37-41$.

[16] Sharma, V.K., R.N. Goswami and M. Kumar. 2006. Effect of different sources and doses of sulphur on yield and quality of sugarcane (Saccharum officinarum L.). Indian Sug., 55(10): 15-19.

[17] Shukla, S.K. and Menhilal. 2002. Competition functions and productivity in sugarcane based associative and successive cropping systems in relation to nitrogen and sulphur nutrition. Indian J. Agric. Sci., 72(6): 315-318.

[18] Singh, R.G. 1972. The microelement nutrition of sugarcane. Co-op. Sug., 4(1): 5-11.

[19] Singh, R.P., H. Ram and Jagdish Prasad. 2002. Effect of pyrites, gypsum and FYM on $\mathrm{pH}$ and yields of paddy and wheat in a sodic soil. Indian J. Agric .Chem., 35(1): 49-51. 


\section{International Journal of Science and Research (IJSR) \\ ISSN (Online): 2319-7064}

Index Copernicus Value (2013): 6.14 | Impact Factor (2015): 6.391

[20] Terry, N. and G. Low. 1982. Leaf chlorophyll content and its relationship to the intercellular localization of iron. J. Pl. Nutr., 5: 301-310.

[21] Tomar, B.S. and S.S. Malik. 2004. Micro-nutrients impacts on growth, yield, quality and staleness of sugarcane variety CoS-8436. Co-op. Sug., 36(3): 255256.

[22] Westerveld,S.M., A.W.Mckeown, D. Scott and M.R.McDonald. 2004. Assessment of chlorophyll and nitrate meters as field tissue nitrogen tests for cabbages, onions and carrots. Hort. Technology 14(2): 179-188.

[23] Yan-Ju Liu, Yi-Ping Tong, Yong-Guan Zhu, Hui Ding and F. Andrew Smith. 2006. Leaf chlorophyll readings as an indicator for spinach yield and nutritional quality with different nitrogen fertilizer applications. Journal of Plant Nutrition, 29: 1207-1217.

[24]Zohlen, A. 2000. The use of 1,10 o-phenanthroline in estimating metabolically active $\mathrm{Fe}$ in plants. Commun. Soil Sci. Pl. Anal., 31: 481-500. 